\title{
Comment
}

\section{United States - Final Dumping Determination on Softwood Lumber from Canada: Recourse to Article 21.5 of the DSU by Canada (Softwood V)}

\section{Prepared for the ALI Project on the Case Law of the WTO}

\author{
MEREDITH A. CROWLEY* \\ Federal Reserve Bank of Chicago, 230 S. LaSalle St., Chicago, IL 60604 \\ Email: mcrowley@frbchi.org
}

This comment summarizes and critiques the analysis of the Softwood V case by Chad P. Bown and Alan O. Sykes. It concurs with their analysis and offers two additional points. First, allowing zeroing in the calculation of dumping margins penalizes foreign exporting firms subject to volatile costs. Second, cost allocation within a multiproduct firm should attempt to equate the real economic returns across products.

Bown and Sykes provide a thorough analysis of the issues raised in the softwood-lumber dispute between the United States and Canada. In this dispute, Canada objected to several of the practices employed by the Commerce Department in calculating dumping margins. Two general substantive questions were at issue. First, how should a government body investigating an allegation of dumping aggregate information from different transactions and different products into a single dumping margin? Second, if an investigating body must construct a cost of production in order to establish a 'normal value', how should this be done in the presence of cross-product subsidization within a firm?

Three specific practices were challenged. First, Canada objected to the use of 'zeroing' in which ostensibly fair-priced transactions are omitted from the weighted-average calculation of a dumping margin. Second, Canada objected to the method the Commerce Department employed to allocate financial expenses

The opinions expressed in this paper are those of the author and do not necessarily reflect those of the Federal Reserve Bank of Chicago or the Federal Reserve System. 
across different product lines within the firm, Abitibi. Lastly, Canada objected to the Commerce Department's use of an internal-transfer price for calculating one Canadian firm's by-product revenue and using an arm's-length-transaction price for calculating by-product revenue for a second firm.

In terms of the legal analysis, Bown and Sykes provide a compelling argument that the text of the Uruguay Round Agreements is vague with no clear statement that zeroing is permitted and no clear statement that it is prohibited. They note that a methodology known as 'weighted average to transaction' that was in use at the time of the Uruguay Round negotiations is clearly discouraged by the text as its use is only permitted in exceptional circumstances. Because this methodology was historically plagued by 'zeroing', Bown and Sykes interpret the text's preference for the two other methodologies, 'weighted average to weighted average' and 'transaction to transaction' as evidence that the Uruguay Round negotiators wished to discourage the use of zeroing in dumping-margin calculations.

However, in the absence of a specific textual prohibition on zeroing under the 'weighted average to weighted average' and 'transaction to transaction' methods, Bown and Sykes find the Appellate Body's rulings questionable. Given the vagueness of the text, they argue that the US's position should have been given deference under the Antidumping Agreement's standard of review.

Regarding their economic analysis of zeroing, Bown and Sykes make an extremely insightful observation. If a government body conducting an investigation into alleged dumping were to compare a time series of prices of a product and a moving average of the same prices, the zeroing methodology would always generate a positive dumping margin, even though the prices are identical.

This note extends this insight from Bown and Sykes to argue that an economic analysis of zeroing suggests that, if the WTO allows zeroing, it is essentially allowing governments to impose a tax on foreign firms that operate in a volatile economic environment. A large economics literature examines the efficiency of antidumping policy. I abstract from the efficiency issues inherent in antidumping policy and ask: if we push a rule to permit zeroing to its extreme, what does this imply about the underlying causes of dumping in a world where zeroing defines the dumping margin?

Consider the following stylized example. Suppose a German firm produces widgets that it sells domestically and exports to the United States. Further suppose that the US dollar/euro exchange rate is volatile, but, for simplicity, assume that it can only take on three possible values, each with equal probability $(0.8 \$$ /euro, $1 \$$ /euro, or $1.2 \$$ /euro). On average, the dollar/euro exchange rate is thus $1 \$$ /euro. It costs the German firm 0.9 euros to make a widget. In the European market, the German firm charges 1 euro per widget, earning a 10 euro-cent profit on each sale. If the German firm charges $\$ 1$ in the US market regardless of the value of the exchange rate on the day the sale takes place (a strategy known as pricingto-market), what are the implications of a rule to allow for zeroing by the US government in an antidumping investigation? 
If the US government uses the German market price as 'normal value' in the dumping-margin calculation, the mathematically defined weighted average of the dumping margin is zero. On one-third of days, the dumping margin is zero because the US price and German price are identical. On one-third of days, there is a negative dumping margin with the US price 20 cents higher than the German price. Only on the final one-third of days is the German firm dumping with the US price 20 cents lower than the German price. However, under the zeroing rule, by ignoring transactions with zero and negative dumping margins, the US would impose an antidumping duty of 6 cents on every imported unit! Even though the firm is not dumping in the traditional sense of systematically price undercutting in the US market (in fact it is systematically charging the same price in both markets), it will be subject to an antidumping duty under the zeroing rule.

What happens if the US government uses German costs to construct a 'normal value' for the dumping-margin calculation? On days when the exchange rate is 1 \$/euro, the German firm will earn a profit of 10 cents on each sale in the US (a negative margin of 10 cents). On days when the exchange rate is $0.8 \$$ /euro, the German firm will earn an even larger profit of 28 cents on each sale. Only on days when the euro is a relatively strong $1.2 \$$ /euro will the German firm suffer a loss of 8 cents on each US sale. Weighting all sales under the zeroing rule implies an antidumping duty of 2.6 cents per widget. However, when we calculate the mathematically defined weighted-average dumping margin, it is a negative 10 cents, reflecting that the firm's average profits on its US sales are 10 cents per unit!

What does this example suggest about the role of zeroing in a volatile economic environment? Firms face uncertainty over their costs from a variety of sources. Exchange rates are highly volatile, notoriously impossible to forecast, and an important area of strategic concern for firms that wish to export. A strategy of setting a foreign-market-currency price that adjusts slowly to movements in the exchange rate seems to be a sensible business practice for two reasons. First, from a logistical standpoint, it would be almost impossible for an exporter to adjust its sales price every day (or even every minute) in response to small exchange-rate movements. Second, both final-goods consumers and intermediate-input purchasers prefer to have some stability in the prices they face. If a foreign firm were to price each and every transaction to the exchange rate of the moment, consumers would almost certainly shift their purchases to domestic sources that didn't insert this added risk.

This suggests that the zeroing rule transforms antidumping policy from a policy intended to prevent systematic price undercutting to one that simply imposes an additional tax on foreign firms because they operate in a volatile economic environment, and the firm cannot feasibly adjust its output price at the same rate at which the exchange rate moves.

The example presented here emphasizes the role of the exchange rate because it is an important cost variable for exporting firms, but the volatile costs confronting firms are not limited to the exchange rate. Energy costs and the costs 
of petroleum-derived inputs are highly volatile. If a firm that is heavily reliant on inputs with volatile prices is subject to an antidumping investigation in which its costs of production are used in constructing a dumping margin, then the firm could be found guilty of dumping under the zeroing rule even when its foreignmarket sales generate profits over a broader time horizon of months, quarters, or years.

From an economic perspective, it seems inconceivable that the Uruguay Round Agreements, whose preamble emphasizes the beneficial role of 'mutually advantageous agreements directed to the substantial reduction of tariffs and other barriers to trade', intended to create, in the form of an antidumping duty that embraces zeroing, a new volatility tax. In a pragmatic sense, volatile exchange rates present a barrier to trade because many firms that would otherwise export are unable to bear exchange-rate risk. To argue that the zeroing rule should be allowed and, thus, to leave firms saddled with not only exchange-rate risk, but also a tax on this risk, seems logically inconsistent at best and a very bad public policy at worst.

Turning to the issues of cross-subsidization within the firm, the text of the Agreement on Antidumping offers little guidance to a national authority. Bown and Sykes conclude that in this environment of little textual guidance, the panel and Appellate Body's decision to side with the US's methodology in the question of cost allocation was reasonable. With regard to the question of transfer pricing, little can be added to Bown and Sykes's point that the correct price to use in constructing a measure of costs is the price that best reflects the real economic value of the product being sold. In most cases, this will be an arm's-lengthtransaction price. The panel and Appellate finding that it was reasonable for the US to use an internal-transfer price for one Canadian firm and to use an arm'slength-transaction price for a second firm seems questionable.

With regard to the question of how best to allocate financing costs, the following point can be added to those raised by Bown and Sykes. In the long run, a multiproduct firm should be equalizing the expected real economic returns across different products. If it is not, then it is wasting resources on unprofitable activities. Economic theory teaches that in the long run, only firms that maximize their profits can survive. However, fluctuations in demand, the costs of inputs, and risk adjustments to financing costs could lead to differences in real economic returns across products in short time periods. Thus, even if a government established rules in which cost allocation was subject to a strict requirement that firms equate real economic returns across products, it would not necessarily be feasible or a good public policy.

To assess the basic arguments put forth by the US and Canada, one can examine their arguments in the context of a production function. Economists use production functions to quantify the 'total factor productivity' (TFP) of firms or of different activities within firms. TFP can be viewed as a rough proxy for real economic returns and, thus, one sensible approach to allocating costs across 
products within a firm would be to allocate costs so as to equate TFP across products. In Softwood V, the US argued that the correct method of allocating financing costs would be to assume that financing costs are proportional to revenues for all products. In contrast, Canada argued that the correct method would be to assume that financing costs are proportional to capital. Both the US and Canadian methods impose restrictions on the firm's production function that are unsupported by any empirical evidence and could even imply that the firm is systematically earning a lower return on one product versus another. In brief, neither leads us closer to what we really want: a method for allocating costs so that real returns are equalized across products.

To summarize the point about cost allocation, economic theory suggests that cost allocation within a firm should be done in a way to equate economic returns across products. However, even in the abstract, there are many legitimate reasons for a firm's behavior to deviate from this. Thus, while the best method should pay heed to this, it is not obvious that it would be appropriate in all circumstances.

In conclusion, I concur with Bown and Sykes's analysis of zeroing. I add to their economic analysis the point that when dumping-margin calculations employ zeroing, antidumping duties are taxes on volatility. With regard to the economics of the problem of cost allocation, I suggest that any methodology should seek to allocate costs so as to equate real economic returns. Finally, Bown and Sykes's analysis of the transfer-price question is perfectly on the mark. 